Research Article

\title{
Isatin Aldazines Synthesis using A Proton Exchanged Algerian Montmorillonite Clay as Acid Eco-friendly Catalyst
}

\author{
Boumadiene Benlahreche ${ }^{1}$, Assya Taleb ${ }^{1}$, Mokhtar B. Lahrech ${ }^{2}$, Salih Hacini1 ${ }^{1, *}$ \\ ${ }^{1}$ Laboratoire de Chimie Fine, Faculté des Sciences Exactes et Appliquées, Université Oran1, BP-1524- \\ Menouar, 31000 - Oran, Algeria \\ ${ }^{2}$ Laboratoire de Chimie Organique et des Substances Naturelles, Faculté des Sciences Exactes et \\ Informatiques, Université Ziane Achour, Djelfa, Algeria
}

Received: 28 $8^{\text {th }}$ March 2019; Revised: 14 $4^{\text {th }}$ May 2019; Accepted: $21^{\text {st }}$ May 2019;

Available online: 30 ${ }^{\text {th }}$ September 2019; Published regularly: December 2019

\section{Abstract}

An efficient and easy procedure is developed for the synthesis of isatin aldazines or bis-Schiff bases of isatin, catalyzed by a proton exchanged Algerian montmorillonite clay $\left(\mathrm{MMT}^{-} \mathrm{H}^{+}\right)$as green catalyst. The products were obtained in two catalyzed steps under conventional heating in ethanol. Isatin-3hydrazone obtained from the reaction of isatin with hydrazine monohydrate reacts in the second step with the appropriate aromatic aldehydes to give the desired products in good yields. The main advantages of using this protonated solid non-toxic catalyst in this synthesis are its availability and low cost, the simplicity of its use, the recycling possibilities without significant loss of its catalytic activity and its environmentally benign process. Copyright (C) 2019 BCREC Group. All rights reserved

Keywords: Montmorillonite- $\mathrm{H}^{+}$; Isatine; Isatin-3-hydrazone; bis-Schiff bases; Isatin Aldazines; Green catalyst

How to Cite: Benlahreche, B., Taleb, A., Lahrech, M.B., Hacini, S. (2019). Isatin Aldazines Synthesis using A Proton Exchanged Algerian Montmorillonite Clay as Acid Eco-friendly Catalyst. Bulletin of Chemical Reaction Engineering \& Catalysis, 14(3): 551-558 (doi:10.9767/bcrec.14.3.4574.551-558)

Permalink/DOI: https://doi.org/10.9767/bcrec.14.3.4574.551-558

\section{Introduction}

Isatin (1H-indole-2,3-dione) and its derivatives possess a broad variety of biological and pharmacological properties [1]. Isatin widely used as starting materials for the synthesis of a broad range of various heterocyclic compounds, including indole, oxoindoles and quinoline [2]. Bis-Schiff bases of isatin also called azines [3] of isatin (Figure 1) are reported to indicate an assortment of biological activities, such as

\footnotetext{
* Corresponding Author.

E-mail: s_hacini@hotmail.com; hacini.salih@univ-oran1.dz (S. Hacini);

Telp: +213662330812, Fax: +21341245089
}

antibacterial [4], antifungal [5], anticancer [6], antiviral [7], antiproliferative [8], antiinflammatory [9], antiglycation [10], antitubercular [11], antioxidant [12,13], anticonvulsant [14], anti-HIV [15,16], cytotoxicity [17], analgesic [18], CNS, depressant [19] and also considered as corrosion inhibitors [20].

Synthesis of isatin-based azines are generally made by condensation of 3-hydrazinoindolin2 -one with aldehydes or ketones to yield respectively isatin aldazines $\left(R_{1}\right.$ or $\left.R_{2}=H\right)$ or isatin ketazines $\left(R_{1}\right.$ and $\left.R_{2} \neq H\right)$ [21]. Most of these synthesis are based mainly on traditional thermal methods in presence of organic solvents and a range of catalysts, such as: acetic acid [22], $\mathrm{HCl}$ [23], triethyl amine [24], $\mathrm{FeCl}_{3} .6 \mathrm{H}_{2} \mathrm{O}$ [25], 
sulphated titania acid [26], $\mathrm{CH}_{3} \mathrm{CO}_{2} \mathrm{Na} / \mathrm{CaCl}_{2}$ [27], nanocrystalline alumina powder [28], or molecular iodine [29]. Therefore, there is a need to use a simple eco-friendly catalyst under moderate conditions to prepare azines.

Green chemistry, in very simple terms, is just a different way of chemistry based mainly on the protection of our environment by preventing pollution and protecting our natural resources. Its basic principles include: avoiding the use of hazardous compounds, using renewable materials and catalysts, improving energy efficiency, etc. [30]. Catalysts used in chemical reactions often have significant environmental problems associated with their chemical nature and reuse as well as the separation and purification of products formed in the reaction mixture. Accordingly, the search for new processes using heterogeneous catalysts more environmentally friendly, represents a major challenge in organic synthesis. Natural and modified mineral clays which are low cost, easily available, as well as environmental friendly, have been used as heterogeneous catalysts for many applications and shown high efficiency in organic synthesis [31].

In this work, we are interested by using this type of catalyst for isatin aldazines synthesis. Therefore, the use of a montmorillonite clay catalyst extracted from North West Algeria, also called Maghnite [35] was proposed, which has already shown interesting catalytic properties [36]. Indeed, montmorillonites which have both Brönsted and Lewis acid sites, produce active acid catalysts when exchanged with high charges density cations, such as: protons. Alge-

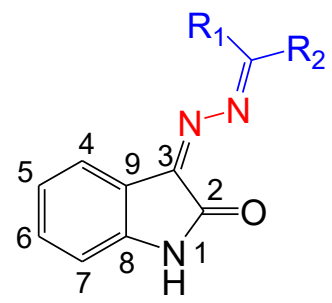

Figure 1. Structure of azines of isatine (or bisSchiff bases of isatin). rian montmorillonite, compared with other clays, contains a high proportion of $\mathrm{SiO}_{2}$ and a lower $\mathrm{Al}_{2} \mathrm{O}_{3}$ concentration. Table 1 shows percentage changes in chemical composition, between raw and proton exchanged algerian MMT. These differences, in particular of $\mathrm{SiO}_{2}$ and $\mathrm{Al}_{2} \mathrm{O}_{3}$, must have a significant impact on the physico-chemical properties of this exchanged montmorillonite. In this case, the decrease of $\mathrm{Al}_{2} \mathrm{O}_{3}$ and the increase of $\mathrm{SiO}_{2}$ would affect the acid-catalyzed reactions, when using this material $[35,36]$. In these conditions, isatin aldazine derivatives 5 a-e have been synthesized in two catalyzed steps by montmorillonite- $\mathrm{H}^{+}\left(\mathrm{MMT}-\mathrm{H}^{+}\right)$in ethanol under conventional heating.

\section{Materials and Methods}

\subsection{Materials}

All commercial reagents and solvents were used as supplied without further purification: isatin $(98 \%, \quad$ Alfa Aesar), 4 hydroxybenzaldehyde (98\%, Sigma-Aldrich), furfural (99\%, Sigma-Aldrich), 4bromobenzaldehyde (99\%, Sigma-Aldrich), 4chlorobenzaldehyde (97\%, Sigma-Aldrich), 4Nitrobenzaldehyde (98\%, Sigma-Aldrich), hydrazine hydrate (80\%, Sigma-Aldrich) and ethanol (96\%, Sigma-Aldrich). Thin layer chromatography (TLC) was done on silica gel TLC aluminium plates (E. Merck Kieselgel 60 F-254) and was visualized by exposure to UV-light at $254 \mathrm{~nm}$ or to iodine vapor for few seconds. ${ }^{1} \mathrm{H}$ and ${ }^{13} \mathrm{C}$ NMR spectra were acquired on a Bruker AQS-AVANCE spectrometer $(400 \mathrm{MHz})$ at $25^{\circ} \mathrm{C}$ using DMSO- $d_{6}$ as solvent. Chemical shifts $(\delta)$ are reported in parts per million (ppm) relative to the internal standard tetramethylsilane (TMS, $\delta=0.00 \mathrm{ppm}$ ). FT-IR spectra were recorded on a Bruker ATR spectrophotometer and the values are expressed in $\mathrm{cm}^{-1}$. Melting point in ${ }^{\circ} \mathrm{C}$ was determined in open capillaries using electrothermal melting point apparatus Stuart MPS-10. Algerian montmorillonite clay extracted from North West Algeria was supplied by "E.N.O.F" (National Company

Table 1. Chemical composition of raw and $\mathrm{H}^{+}$exchanged Algerian montmorillonite [35].

\begin{tabular}{lccccccccccc}
\hline \multicolumn{1}{c}{ Sample } & $\mathrm{SiO}_{2}$ & $\mathrm{Al}_{2} \mathrm{O}_{3}$ & $\mathrm{Fe}_{2} \mathrm{O}_{3}$ & $\mathrm{MgO}$ & $\mathrm{CaO}$ & $\mathrm{Na}_{2} \mathrm{O}$ & $\mathrm{K}_{2} \mathrm{O}$ & $\mathrm{TiO}_{2}$ & $\mathrm{SO}_{3}$ & $\mathrm{As}$ & $\begin{array}{c}\text { Water loss at } \\
110{ }^{\circ} \mathrm{C}\end{array}$ \\
\hline $\begin{array}{l}\text { Alg-MMT raw } \\
(\%)\end{array}$ & 69.39 & 14.67 & 1.16 & 1.07 & 0.3 & 0.5 & 0.79 & 0.16 & 0.91 & 0.05 & 11 \\
$\begin{array}{l}\text { Alg-MMT-H+ } \\
(\%)\end{array}$ & 71.7 & 14.03 & 0.71 & 0.8 & 0.28 & 0.21 & 0.77 & 0.15 & 0.34 & 0.01 & 11 \\
\hline
\end{tabular}


for non-ferrous mining products and useful substances).

\subsection{Preparation of Montmorillonite- $\mathrm{H}^{+}$}

Exchanged montmorillonite- $\mathrm{H}^{+}\left(\mathrm{MMT}-\mathrm{H}^{+}\right)$ was prepared according to the literature [35]. Raw montmorillonite (20 g) was crushed for 20 min and oven dried at $105^{\circ} \mathrm{C}$ for 2 hours. The montmorillonite was then weighted and placed in an erlenmeyer flask together with $500 \mathrm{ml}$ of distilled water. The montmorillonite/water mixture was stirred using a magnetic stirrer and combined with $500 \mathrm{~mL}$ sulphuric acid solution (0.5 M) until saturation was achieved after two days at room temperature. The mineral was washed with distilled water until became sulphate free and then dried at $105^{\circ} \mathrm{C}$. The montmorillonite- $\mathrm{H}^{+}$prepared is ready to be used directly to catalyze our reactions.

2.3 General Procedure for the Synthesis of 3hydrazonoindoline-2-one 3

Isatin 1 (1 mmol) and hydrazine monohydrate $2(80 \%, 2 \mathrm{mmol})$ are added to catalytic amount of montmorillonite- $\mathrm{H}^{+}(10 \%, 0.0147 \mathrm{~g})$ in $10 \mathrm{~mL}$ ethanol. The amount of $10 \%$ of catalyst was selected after preliminary reaction tests. The reaction mixture was refluxed for 1 $\mathrm{h}$. When the yellowish product was observed and the reaction completed (monitored by TLC), the crude product was dissolved in hot ethanol and then filtered to remove the solid filtered, filtered, washed with cold water, ethanol and dried at $60-70{ }^{\circ} \mathrm{C}$ to afford compound 3 catalyst. The filtrate was cooled to give the sol-

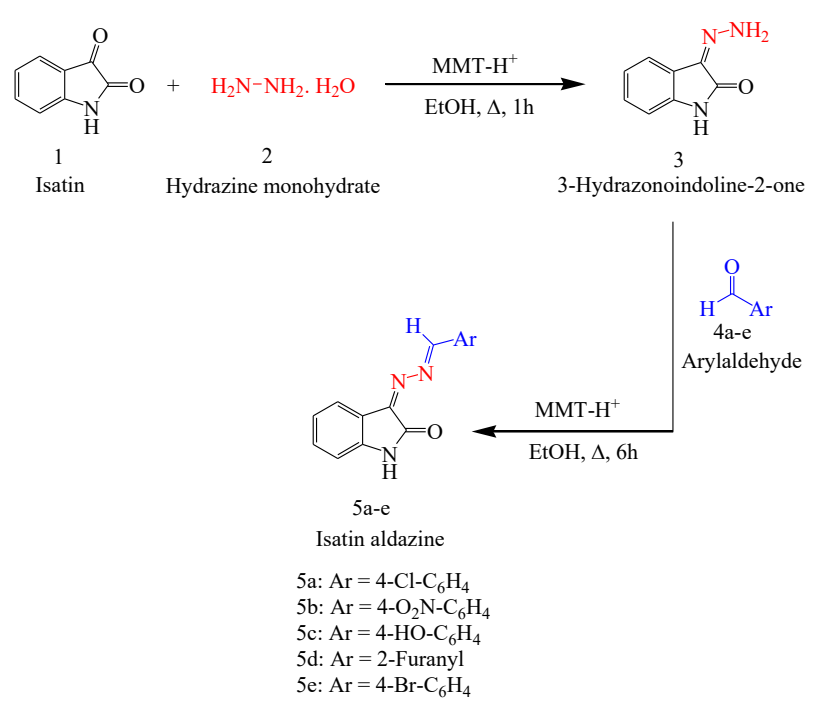

Scheme 1. Synthesis of isatin aldazine derivatives 5 a-e catalyzed by MMT- ${ }^{+}$ id product. The crystalline powder was which was used for next step without any further purification.

Data for 3-hydrazonoindoline-2-one 3: yellow powder (yield $86 \%$ ), m.p. $225-227{ }^{\circ} \mathrm{C}$ (Lit. 226-228 $\left.{ }^{\circ} \mathrm{C}\right)$ [12,16]; FT-IR $\left(v_{\max }\right.$ in $\left.\mathrm{cm}^{-1}\right): 3354$ $(\mathrm{N}-\mathrm{H}), 3151$ (N-H Isatin), $1655(\mathrm{C}=\mathrm{O}), 1602$ $(\mathrm{C}=\mathrm{N}), 1549$ (aromatic $\mathrm{C}=\mathrm{C}) ;{ }^{1} \mathrm{H}$ NMR $(400$ MHz, DMSO- $d_{6}, \delta$ in ppm): $10.70(\mathrm{~s}, 1 \mathrm{H}, \mathrm{NH})$, $10.54\left(\mathrm{~d}, J=14.2 \mathrm{~Hz}, 1 \mathrm{H},-\mathrm{NH}_{2}\right), 9.56(\mathrm{~d}, J=$ $\left.14.2 \mathrm{~Hz}, 1 \mathrm{H},-\mathrm{NH}_{2}\right), 7.36\left(\mathrm{~d}, J=7.8 \mathrm{~Hz}, 1 \mathrm{H}, \mathrm{H}_{7}\right.$ of isatin), 7.15 ( $t, J=7.5 \mathrm{~Hz}, 1 \mathrm{H}, \mathrm{H}_{6}$ of isatin), 6.97 (t, $J=7.5 \mathrm{~Hz}, 1 \mathrm{H}, \mathrm{H}_{5}$ of isatin), $6.86(\mathrm{~d}, J$ $=7.8 \mathrm{~Hz}, 1 \mathrm{H}, \mathrm{H}_{4}$ of isatin); ${ }^{13} \mathrm{C} \mathrm{NMR}(100 \mathrm{MHz}$, DMSO- $d_{6}, \delta$ in ppm): $110.43,117.91,121.82$, 126.65, 127.50, 139.10, 163.24, $206.99(\mathrm{C}=\mathrm{O})$.

2.4 General Procedure for the Synthesis of Isatin Aldazines 5a-e

The 3-hydrazonoindoline-2-one 3 (1 mmol) is added to arylaldehyde $4 \mathrm{a}-\mathrm{e}(1 \mathrm{mmol})$ in $10 \mathrm{ml}$ ethanol with catalytic amount of montmorillonite- $\mathrm{H}^{+}(10 \%)$. The reaction mixture is refluxed for $6 \mathrm{~h}$ during which the solution color change. The progress of reaction is monitored by TLC. The crude product is dissolved with hot ethanol and then filtered to remove the solid catalyst. The filtrate is cooled to give the solid product. The crystalline powder is filtered, washed with ethanol and dried at 60-70 ${ }^{\circ} \mathrm{C}$ to afford compound 5a-e (Scheme 1).

\subsection{Characterization and Spectroscopic Data}

Data for 3-((4-Chlorobenzylidene) hydrazono)indolin-2-one 5a: orange powder (yield 84\%), m.p. $269-271{ }^{\circ} \mathrm{C}$ (lit. $270-272{ }^{\circ} \mathrm{C}$ ) [21]; FT-IR $\left(v_{\max }\right.$ in $\left.\mathrm{cm}^{-1}\right): 3276(\mathrm{~N}-\mathrm{H}), 3053$ (aromatic C-H), $1718(\mathrm{C}=\mathrm{O}), 1611(\mathrm{C}=\mathrm{N}), 1590$ (aromatic $\mathrm{C}=\mathrm{C}$ ), 749 (C-Cl); ${ }^{1} \mathrm{H}$ NMR $\left(400 \mathrm{MHz}, \mathrm{DMSO}-d_{6}, \delta\right.$ in ppm): 10.86 (s, 1H,-NH-), $8.62(\mathrm{~s}, 1 \mathrm{H},-\mathrm{N}=\mathrm{CH})$, $8.00(\mathrm{~d}, J=8.4 \mathrm{~Hz}, 2 \mathrm{H}, \mathrm{Ar}-\mathrm{H}), 7.87(\mathrm{~d}, J=8.4$ $\mathrm{Hz}, 2 \mathrm{H}, \mathrm{Ar}-\mathrm{H}), 7.65\left(\mathrm{~d}, J=7.5 \mathrm{~Hz}, 1 \mathrm{H}, \mathrm{H}_{7}\right.$ of isatin), $7.41\left(\mathrm{t}, J=7.8 \mathrm{~Hz}, 1 \mathrm{H}, \mathrm{H}_{6}\right.$ of isatin), $7.03\left(\mathrm{t}, J=7.8 \mathrm{~Hz}, 1 \mathrm{H}, \mathrm{H}_{5}\right.$ of isatin), $6.91(\mathrm{~d}, J$ $=7.5 \mathrm{~Hz}, 1 \mathrm{H}, \mathrm{H}_{4}$ of isatin); ${ }^{13} \mathrm{C}$ NMR $(100 \mathrm{MHz}$, DMSO- $d_{6}, \delta$ in ppm): $111.38,111.98,116.79$, $122.87,129.26,129.84,130.91,132.77,134.33$, $137.17,141.72,145.60,150.80,159.29,164.88$ $(\mathrm{C}=\mathrm{O})$.

Data for 3-((4-Nitrobenzylidene) hydrazono)indolin-2-one $5 \mathrm{~b}$ : orange powder (yield 78\%), m.p. 252-254 ${ }^{\circ} \mathrm{C}$ (lit. 254-256 ${ }^{\circ} \mathrm{C}$ ) [21]; FT-IR $\left(v_{\max }\right.$ in $\left.\mathrm{cm}^{-1}\right): 3277 \quad(\mathrm{~N}-\mathrm{H}), \quad 3052$ (aromatic C-H), $1719(\mathrm{C}=\mathrm{O}), 1612(\mathrm{C}=\mathrm{N}), 1591$ (aromatic $\mathrm{C}=\mathrm{C}), 1327\left(\mathrm{C}-\mathrm{NO}_{2}\right) ;{ }^{1} \mathrm{H}$ NMR $(400$ MHz, DMSO- $d_{6}, \delta$ in ppm): 10.90 (s, $\left.1 \mathrm{H},-\mathrm{NH}-\right)$, 
8.67(s, $1 \mathrm{H}, \mathrm{N}=\mathrm{CH}), 8.39(\mathrm{~d}, J=8.7 \mathrm{~Hz}, 2 \mathrm{H}, \mathrm{Ar}-$ $\mathrm{H}), 8.21(\mathrm{~d}, J=8.7 \mathrm{~Hz}, 2 \mathrm{H}, \mathrm{Ar}-\mathrm{H}), 7.74(\mathrm{~d}, J=$ $7.8 \mathrm{~Hz}, 1 \mathrm{H}, \mathrm{H}_{7}$ of isatin), $7.42(\mathrm{t}, J=7.5 \mathrm{~Hz}, 1 \mathrm{H}$, $\mathrm{H}_{6}$ of isatin), $7.02\left(\mathrm{t}, J=7.5 \mathrm{~Hz}, 1 \mathrm{H}, \mathrm{H}_{5}\right.$ of isatin), $6.92\left(\mathrm{~d}, J=7.8 \mathrm{~Hz}, 1 \mathrm{H}, \mathrm{H}_{4}\right.$ of isatin); ${ }^{13} \mathrm{C}$ NMR $\left(100 \mathrm{MHz}\right.$, DMSO- $d_{6}, \delta$ in ppm): 111.50 , $111.85,116.54,122.29,122.94,124.75,129.21$, $130.16,134.61,139.58,145.78,149.51,150.18$, $156.77,164.63(\mathrm{C}=\mathrm{O})$.

Data for 3-(2-(4-hydroxybenzylidene) hydrazono)indolin-2-one 5c: orange powder (yield $80 \%$ ), m.p. $261-263 \quad{ }^{\circ} \mathrm{C} \quad$ (lit. $261{ }^{\circ} \mathrm{C}$ ) [10,11,12,33,34]; FT-IR $\left(v_{\max }\right.$ in $\left.\mathrm{cm}^{-1}\right): 3397(\mathrm{O}$ -

Table 2. Physical data of the synthesized compounds 5a-e using montmorillonite- $\mathrm{H}^{+}$.

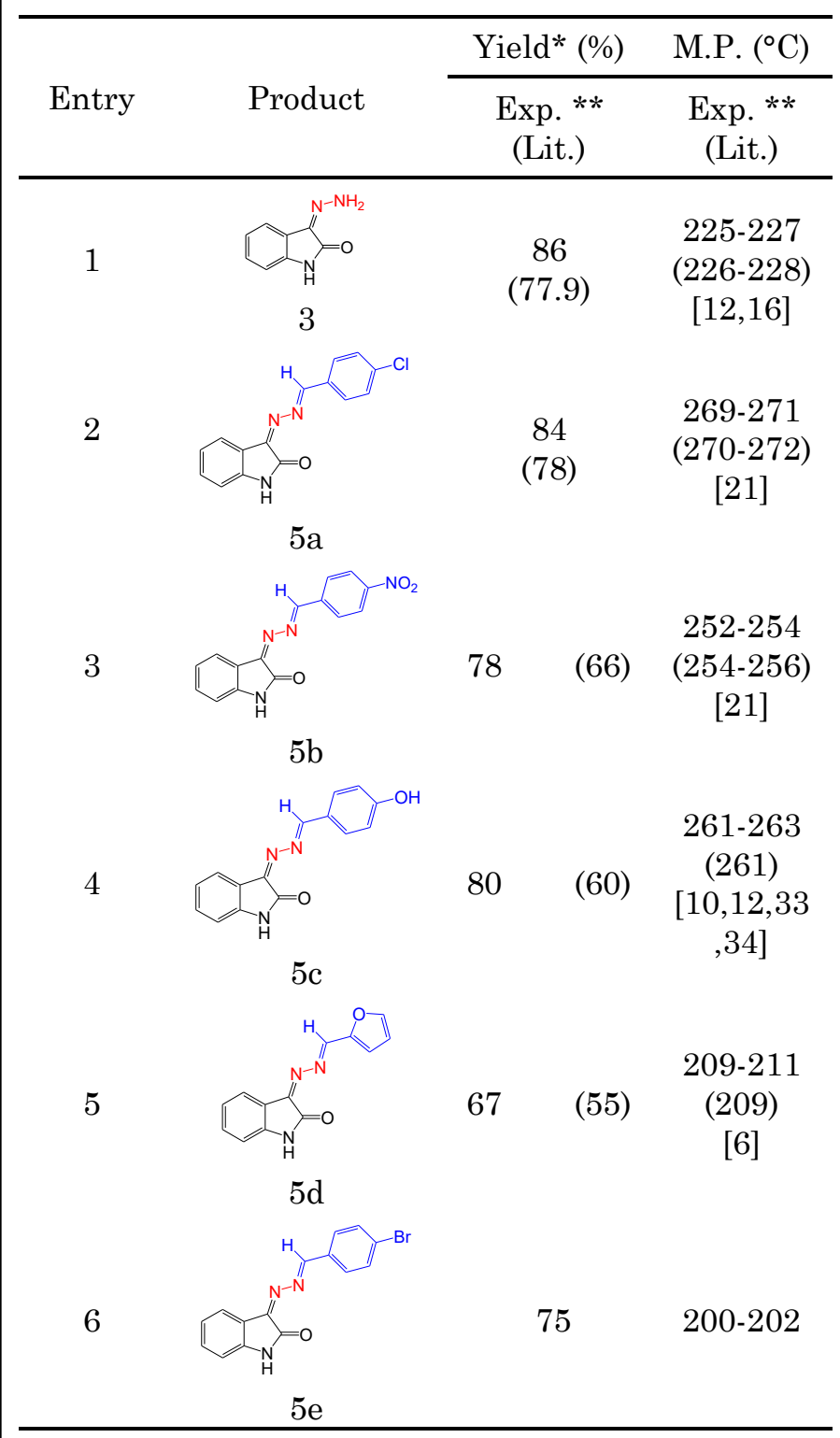

$\left(^{*}\right)$ Isolated yield of product using montmorillonite- $\mathrm{H}^{+}$. The structure of products are determined by NMR and all spectral data are in good agreement with those of literature.

(**) Exp.: Experimental value (Lit.: literature value).
H), $3149(\mathrm{~N}-\mathrm{H}), 3047$ (aromatic $\mathrm{C}-\mathrm{H}), 1680$ $(\mathrm{C}=\mathrm{O}), 1614(\mathrm{C}=\mathrm{N}), 1541$ (aromatic $\mathrm{C}=\mathrm{C}), 1092$ (C-O); ${ }^{1} \mathrm{H}$ NMR $\left(400 \mathrm{MHz}, \mathrm{DMSO}-d_{6}, \delta\right.$ in ppm): 10.79 (s, $1 \mathrm{H},-\mathrm{NH}-), 10.36$ (s, $1 \mathrm{H},-\mathrm{OH}), 8.61$ (s, $1 \mathrm{H}, \mathrm{N}=\mathrm{CH}), 8.10\left(\mathrm{~d}, J=7.5 \mathrm{~Hz}, 1 \mathrm{H}, \mathrm{H}_{7}\right.$ of isatin), $7.87(\mathrm{~d}, J=8.6 \mathrm{~Hz}, 2 \mathrm{H}, \mathrm{Ar}-\mathrm{H}), 7.39$ (t, $J=$ $7.8 \mathrm{~Hz}, 1 \mathrm{H}, \mathrm{H}_{6}$ of isatin), $7.05(\mathrm{t}, J=7.8 \mathrm{~Hz}$, $1 \mathrm{H}, \mathrm{H}_{5}$ of isatin), $6.96(\mathrm{~d}, J=8.6 \mathrm{~Hz}, 2 \mathrm{H}, \mathrm{Ar}-$ $\mathrm{H}), 6.90\left(\mathrm{~d}, J=7.5 \mathrm{~Hz}, 1 \mathrm{H}, \mathrm{H}_{4}\right.$ of isatin); ${ }^{13} \mathrm{C}$ NMR $\left(100 \mathrm{MHz}\right.$, DMSO- $d_{6}, \delta$ in ppm): 111.15 , $116.66,116.67,117.23,122.75,125.05,129.38$, 131.87, 131.88, 133.78, 145.22, 151.16, 162.10, 163.47, $165.33(\mathrm{C}=\mathrm{O})$.

Data for 3-((Furan-2-ylmethylene) hydrazono)indolin-2-one 5d: yellow powder (yield $67 \%$ ), m.p. $209-211^{\circ} \mathrm{C}$ (lit. $209^{\circ} \mathrm{C}$ ) [6]; FT-IR ( $v_{\max }$ in $\left.\mathrm{cm}^{-1}\right): 3276(\mathrm{~N}-\mathrm{H}), 3054$ (aromatic $\left.\mathrm{C}-\mathrm{H}\right), 1720$ $(\mathrm{C}=\mathrm{O}), 1613(\mathrm{C}=\mathrm{N}), 1590$ (aromatic $\mathrm{C}=\mathrm{C}) ;{ }^{1} \mathrm{H}$ NMR (400 MHz, DMSO- $d_{6}, \delta$ in ppm): 10.82 (s, $1 \mathrm{H},-\mathrm{NH}-), 8.50(\mathrm{~s}, 1 \mathrm{H}, \mathrm{N}=\mathrm{CH}), 8.08(\mathrm{~d}, J=8.1$ $\mathrm{Hz}, 2 \mathrm{H}, \mathrm{Ar}-\mathrm{H}), 7.40\left(\mathrm{t}, J=7.5 \mathrm{~Hz}, 1 \mathrm{H}, \mathrm{H}_{6}\right.$ of isatin), $7.34\left(\mathrm{~d}, J=7.8 \mathrm{~Hz}, 1 \mathrm{H}, \mathrm{H}_{7}\right.$ of isatin), $7.04\left(\mathrm{t}, J=7.5 \mathrm{~Hz}, 1 \mathrm{H}, \mathrm{H}_{5}\right.$ of isatin), $6.90(\mathrm{~d}, J=$ $7.8 \mathrm{~Hz}, 1 \mathrm{H}, \mathrm{H}_{4}$ of isatin), $6.80(\mathrm{~d}, J=1.7 \mathrm{~Hz}$, $1 \mathrm{H}, \mathrm{Ar}-\mathrm{H}) ;{ }^{13} \mathrm{C}$ NMR $\left(100 \mathrm{MHz}, \mathrm{DMSO}-d_{6}, \delta\right.$ in ppm): 111.25, 113.64, 117.18, 120.17, 122.76, 129.51, 134.16, 145.39, 148.52, 149.55, 151.24, $151.80,165.13(\mathrm{C}=\mathrm{O})$.

Data for 3-(2-(4-bromobenzylidene) hydrazono)indolin-2-one 5e: Yellow powder (yield 75\%), m.p. $200-202{ }^{\circ} \mathrm{C}$; FT-IR $\left(v_{\max }\right.$ in $\left.\mathrm{cm}^{-1}\right): 3274.17$ (N-H), 3055 (aromatic C-H), $1719(\mathrm{C}=\mathrm{O}), 1612$ $(\mathrm{C}=\mathrm{N}), 1590$ (aromatic $\mathrm{C}=\mathrm{C}), 750(\mathrm{C}-\mathrm{Br}) ;{ }^{1} \mathrm{H}$ NMR (400 MHz, DMSO- $d_{6}, \delta$ in ppm): 11.00 (s, $1 \mathrm{H},-\mathrm{NH}-), 8.64(\mathrm{~s}, 1 \mathrm{H},-\mathrm{N}=\mathrm{CH}), 7.99(\mathrm{~d}, J=8.1$ $\mathrm{Hz}, 2 \mathrm{H}, \mathrm{Ar}-\mathrm{H}), 7.62(\mathrm{~d}, J=8.0 \mathrm{~Hz}, 2 \mathrm{H}, \mathrm{Ar}-\mathrm{H})$, $8.00\left(\mathrm{~d}, J=7.8 \mathrm{~Hz}, 1 \mathrm{H}, \mathrm{H}_{7}\right.$ of isatin), 7.60 (t, $J$ $=7.5,1 \mathrm{H}, \mathrm{H}_{6}$ of isatin), $7.57(\mathrm{t}, J=7.5 \mathrm{~Hz}, 1 \mathrm{H}$, $\mathrm{H}_{5}$ of isatin), $6.87\left(\mathrm{~d}, J=7.8 \mathrm{~Hz}, 1 \mathrm{H}, \mathrm{H}_{4}\right.$ of isatin); ${ }^{13} \mathrm{C}$ NMR $\left(100 \mathrm{MHz}\right.$, DMSO- $d_{6}, \delta$ in ppm): $113.59,114.01,118.17,124.88,130.13,131.12$, $136.80,139.36,144.91,149.34,149.68,157.55$, $164.17(\mathrm{C}=\mathrm{O})$.

\section{Results and Discussion}

The reaction of isatin 1 with hydrazine hydrate 2 provides 3 -hydrazonoindoline-2-one 3 which is condensed with aromatic aldehydes 4a-e to yield the desired products 5a-e (Scheme 1). This two steps reactional sequence is catalyzed by proton exchanged Algerian montmorillonite $\left(\mathrm{MMT}^{-} \mathrm{H}^{+}\right)$. The experimental results (Table 2) obtained by these reactions show good yields compared to those of the literature. Furthermore, the catalyst can be removed from the reactional mixture and recycled up to three times without loss of catalytic activity. 
A mechanism, presented in Scheme 2, is proposed to explain the role of the proton exchanged montmorillonite catalyst $\left(\mathrm{MMT}-\mathrm{H}^{+}\right)$in the two steps isatin aldazines synthesis 5a-e. The structures of compounds 5a-e were confirmed by their melting points and the analysis of their spectral data (FT-IR spectroscopy, ${ }^{1} \mathrm{H}$ and ${ }^{13} \mathrm{C}$ ), compared to the values of the literature.

\subsection{Infrared Spectroscopy (FT-IR)}

The FT-IR spectrum of all synthesized compounds show characteristic bands at 33543400, 3149-3277, $1680-1720 \mathrm{~cm}^{-1}$ and a weak broad band in 1611-1673 $\mathrm{cm}^{-1}$ region, which can be assigned respectively to $-\mathrm{NH}_{2}, \mathrm{~N}-\mathrm{H}$ (isatin), $\mathrm{C}=\mathrm{O}$ and $\mathrm{C}=\mathrm{N}$ (azomethine linkage) vibrations of 3 -hydrazinoindolin-2-one $3[6,15,16]$. This is a direct evidence of the condensation of hydrazine hydrate 2 on the carbonyl in position 3 of isatin 1 and confirms the formation of the de- sired Schiff bases. The IR spectra of isatin aldazine derivatives 5a-e showed new strong bands at $1536-1591$ and $1006-1027 \mathrm{~cm}^{-1}$ regions, which assignable to aromatic $(\mathrm{C}=\mathrm{C})$ and hydrazinic $(\mathrm{N}-\mathrm{N})$ vibrations respectively. IR spectrum of 3-(2-(4-hydroxybenzylidene) hydrazono)indolin- 2-one 5c show a large absorption band in the region of 3400-3393 $\mathrm{cm}^{-1}$ assignable to $\mathrm{O}-\mathrm{H}$ (intermolecular hydrogen bonded) stretching [10-12,33,34]. The IR spectra of compound 3-((4-nitrobenzylidene)hydrazo no)indolin-2-one $5 \mathrm{~b}$ show strong band at $1290-1330 \mathrm{~cm}^{-1}$ assigned to (N-O) stretching vibrations in nitro group. For compounds 3-((4chlorobenzylidene)hydrazono)indolin-2-one $5 \mathrm{a}$ and 3-(2-(4-bromobenzylidene)hydrazono) indolin-2-one 5e, C-halogen bonds displayed absorption around $610-750 \mathrm{~cm}^{-1}$ which can be assigned to $(\mathrm{C}-\mathrm{Cl})$ and $(\mathrm{C}-\mathrm{Br})$ stretching vibrations respectively. The furanyl derivative 3((furan-2-ylmethyl ene)hydrazono)indolin-2-one

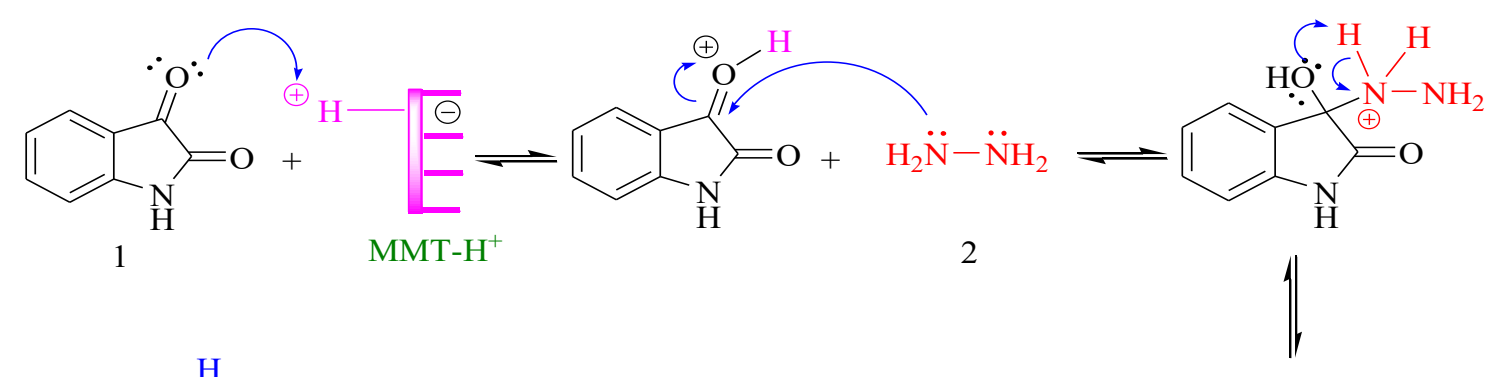

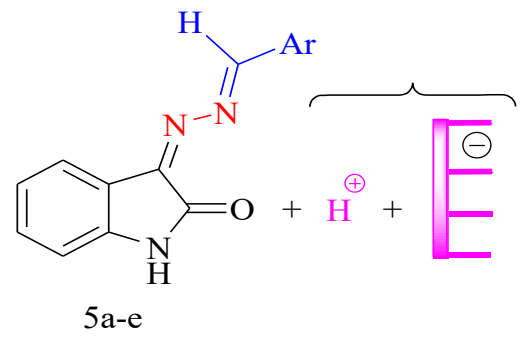<smiles>NNC1Oc2ccccc2NC1=O</smiles><smiles>[3H]C(=[V])/C=N/N=C1\C(=O)Nc2ccccc21</smiles>

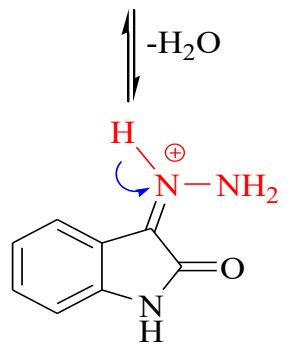

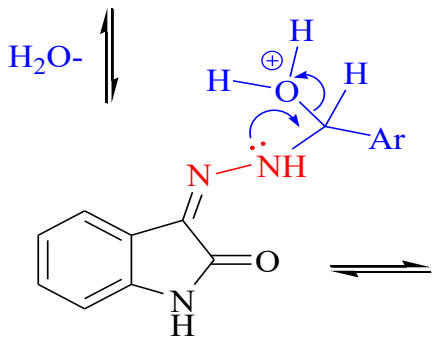

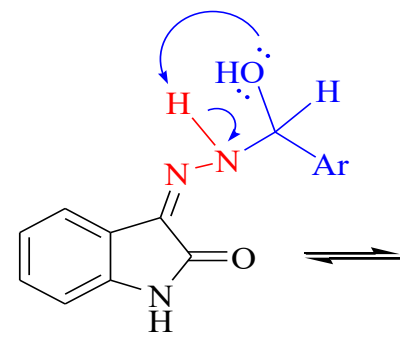

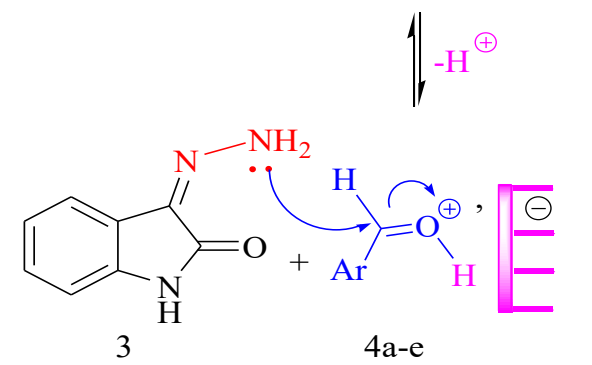

Scheme 2. Proposed mechanism for the synthesis of isatin aldazine 5a-e in two steps using MMT-H ${ }^{+}$ 
$5 \mathrm{~d}$ shows absorption bands at $1283-1328 \mathrm{~cm}^{-1}$, attributed to (C-O) covalent bond.

\subsection{Nuclear Magnetic Resonance (NMR)}

In ${ }^{1} \mathrm{H}-\mathrm{NMR}$, spectra of all synthesized compounds show singlet at $10.79-11.11 \mathrm{ppm}$ indicating the presence of secondary amino group $(\mathrm{NH})$ of isatin skeleton. The aromatic protons resonate as multiplet in the region of $\delta$ 6.80-8.39 ppm. The spectrum of 3hydrazinoindolin-2-one 3 shows the $-\mathrm{NH}_{2}$ signal around 10.54-9.56 ppm. The signal of azomethine $(-\mathrm{CH}=\mathrm{N})$ appear at $\delta 8.50-9.00 \mathrm{ppm}$ in all the 5a-e compounds [10,21,33,34]. The absence of $-\mathrm{NH}_{2}$ signal clearly indicates the formation of isatin aldazines 5a-e. Moreover, the ${ }^{1} \mathrm{H}-\mathrm{NMR}$ spectrum of $5 \mathrm{c}$ reveal the presence of a singlet at 8-10.36 ppm corresponding to hydroxyl group $\mathrm{O}-\mathrm{H}$. All ${ }^{1} \mathrm{H}$ - and ${ }^{13} \mathrm{C}-\mathrm{NMR}$ spectral data are in good agreement with those of literature.

\section{Conclusions}

The montmorillonite- $\mathrm{H}^{+} \quad\left(\mathrm{MMT}-\mathrm{H}^{+}\right)$was found to be an efficient green heterogeneous acidic catalyst for the synthesis of isatin aldazine derivatives. This catalyst was easy to prepare, environmentally friendly, highly stable and can be recycled without significant loss of activity. The distinguished advantageous of present synthetic method are use of inexpensive catalyst, simple reaction workup, good yields and reusability of catalyst. Other applications of this catalyst in synthetic processes are under study.

\section{Acknowledgments}

The authors would like to thank the Université Oran1, University of Djelfa and DGRSDT (MESRS) for research facilities and financial support. We also thank Pr. Pierre Van de Weghe, Université Rennes 1 (France) for NMR analysis of our samples.

\section{References}

[1] Liu, Y.C., Zhang, R., Wu, Q.Y., Chen, Q., Yang, G.F. (2014). Recent developments in the synthesis and applications of isatins. Org. Prep. Proceed. Int., 46: 317-362, doi:10.10 80/00304948.2014.922378.

[2] Da Silva, J.F., Garden S.J., Pinto, A.C. (2001). The chemistry of isatins: a review from 1975 to 1999. J. Braz. Chem. Soc., 12: 273-324.

[3] Safari, J., Gandomi-Ravandi, S.R. (2014). Structure, synthesis and application of azines: a historical perspective. $R S C A d v ., 4: 46224$ 46249, doi: 10.1039/c4ra04870a.

[4] Swathy, S.S., Joseyphus, R.S., Nisha, V.P., Subhadrambika, N., Mohanan, K. (2016). Synthesis, spectroscopic investigation and antimicrobial activities of some transition metal complexes of a [(2-hydroxyaceto phenone)-3isatin]bishydrazone. Arab. J. Chem., 9: S1847-S1857, doi: 10.1016/j.arabjc.20 12.05.004.

[5] Vasanthi, R., Rajendraprasad, Y., Srinivas, B. (2013). Synthesis, Charac- terization, Antibacterial and Anti- fungal Activities of Isatin Derivatives. Int. J. Chem. Tech. Res., 5(6): 3015-3022.

[6] Dweedar, H.E., Mahrous, H., Ibrahim, H.S., Abdel-Aziz, H.A. (2014). Analogue-based design, synthesis and biological evaluation of 3 substituted-(methylenehydrazono)indolin-2ones as anticancer agents. Eur. J. Med. Chem., 78: 275-280, doi: 10.1016/j.ej mech.2014. 03.058.

[7] Jarrahpour , A., Sheikh, J., El Mounsi, I., Juneja, H., Ben Hadda, T. (2012). Computational evaluation and experimental in vitro antibacterial, antifungal and antiviral activity of bis-Schiff bases of isatin and its derivatives. Med. Chem. Res., 22(3): 1203-1211, doi: 10.1007/s00044-012-0127-6.

[8] Eldehna, W.M., Al-Wabli, R.I., Almutairi, M.S., Keeton, A.B., Piazza, G.A., Abdel-Aziz, H.A., Attia, M.I. (2018). Synthesis and biological evaluation of certain hydra zonoindolin-2-one derivatives as new potent anti-proliferative agents. J. Enzyme. Inhib. Med. Chem., 33(1): 867-878, doi:10.1080/ 14756366.2018. 1462802 .

[9] Kerzare, D., Chikhale, R., Ban- sode, R., Amnerkar, N., Karodia, N., Paradkar, A., Khedekar. P. (2016). Design, Synthesis, Pharmacological Evaluation and Molecular Docking Studies of Substituted Oxadiazolyl2-Oxoindolinylidene Propane Hydrazide Derivatives., J. Braz. Chem. Soc., 27(11): 19982010, doi: 10.5935/010 3-5053.20160090.

[10] Khan, K.M., Khan, M., Ali, M., Taha, M., Rasheed, S., Perveen, S., Choudhary, M.I. (2009). Synthesis of bis-Schiff bases of isatins and their antiglycation activity. Bioorg. Med. Chem.,17: 7795-7801, doi:10.1016/j.b mc.2009.09.028.

[11] Suresh, A.J., Lakshmi, S.G., Kumar, V.S., Madhuraj, M., Durga, V., Surya, P.R. (2018). Design, synthesis, characterization, and biological evaluation of some novel antitubercular agents targeting thymidylate synthetase, enoyl-ACP reductase, and l, d-trans peptidase-2. J. Pharm. Res., 12(3): 332-339. 
[12] Khan, K.M., Khan, M., Ambreen, N., Rahim, F., Muhammad, B., Ali, S., Haider, S.M., Perveenb, S., Choudhary, M.I. (2011). BisSchiff Bases of Isatins: A New Class of Antioxidant. J. Pharm. Res., 4(10): 34 02-3404.

[13] Khan, Z., Maqsood, Z.T., Tanoli, M.A.K., Khan, K.M., Iqbal, L., Lateef, M. (2015). Synthesis, Characterization, In-Vitro Antimicrobial and Antioxidant Activities of $\mathrm{Co}^{+2}, \mathrm{Ni}^{+2}$, $\mathrm{Cu}^{+2}$ and $\mathrm{Zn}^{+2}$ Complexes of 3-(2-(2-hydroxy-3methoxybenzylid ene)hydrazono)indolin-2one. J. Basic. Appl. Sci. 11: 125-130, doi: 10.6000/1927-5129.2015.11.17

[14] Prakash, C.R., Raja, S., Saravanan, G. (2010). Synthesis, Characterization and anticonvulsant activity of novel Schiff base of isatin derivatives. Int. J. Pharm. Pharm. Sci, 2(4): $177-181$

[15] Oguntoye, O.S., Hamid, A.A., Iloka, G.S., Bodede, S.O., Owalude, S.O., Tella, A.C. (2016). Synthesis and spectroscopic analysis of Schiff Bases of Imesatin and Isatin derivatives. J. Appl. Sci. Environ. Manage., 20 (3): 653-657, doi: 10.4314/jasem.v20i3.20.

[16] Sunday, I.G., Christiana, K.A., Sunday, B., Olubunmi, O.S. (2016). Synthesis and Spectroscopic analysis of Schiff bases of Isatin and Imesatin derivatives. I.J.S.E.A.S., 2(4):381388.

[17] Ibrahim, H.S., Abou-seri, S.M., Ismail, N.S. M., Elaasser, M.M., Aly, M.H., Abdel-Aziz, H.A. (2016). Bis-isatin hydrazones with novel linkers: synthesis and biological evaluation as cytotoxic agents. Eur. J. Med. Chem., 108: 415-422, doi:10.1016/j.ejmech. 2015.11.047.

[18] Saxena, A., Das, D.R., Saxena, S. (2015). Synthesis, Anti TB, Anti oxidant, Antimicrobial Activity of some Isatin-3-hydrazone derivatives. Chem. Sci. Rev. Lett., 4(14), 729-734.

[19] Prince, P.S., Pandeya, S.N., Roy, R.K., Verma, K., Gupta,S. (2009). Synthesis and Anticonvulsant activity of some Novel Isatin Schiff's bases. Int. J. Chem. Tech. Res., 1(3): 758-763.

[20] Ansari, K.R., Quraishi, M.A. (2014). Bis-Schiff bases of isatin as new and environmentally benign corrosion inhibitor for mild steel. $J$. Ind. Eng. Chem., 20(5): 2819-2829, doi:10.1016/j.jiec.2013.11.014.

[21] Ibrahim, H.S., Abdelhadi, S.R., Abdel-Aziz, H.A. (2015). Hydrolysis and Hydrazinolysis of Isatin-Based Ald- and Ketazines. J. Chem., 16, doi: 10.1155/2015/826489.

[22] Shingade, S.G., Sanjaykumar, Bari, B., Waghmare, U.B. (2012). Synthesis and antimicrobial activity of 5-chloroindoline-2,3dione derivatives. Med. Chem. Res., 21: 13021312, doi: 10.1007/s00044-011-9644-y.
[23] Siddappa, K., Mayana, N.S. (2014). Synthesis, Spectroscopic Characterization, and Biological Evaluation Studies of 5-Bromo-3( ( ( hy d roxy-2-methylquinolin - 7 yl)methylene)hydrazono)indolin-2-one and Its Metal (II) Complexes. Bioinorg. Chem. Appl., 11, doi: 10.1155/2014/483282.

[24] Safari, J., Gandomi-Ravandi, S. (2011). Highly efficient practical procedure for the synthesis of azine derivatives under solvent-free conditions. Synth. Commun., 41: 645-651, doi: $10.1080 / 00397911003629523$.

[25] Eshghia, H., Hosseini, M. (2008). Selective and Convenient Protection of Aldehydes as Azines under Solvent-Free Conditions. J. Chin. Chem. Soc., 55: 636-638.

[26] Krishnakumar, B., Swaminathan, M. (2011). An expeditious and solvent free synthesis of azine derivatives using sulfated anatasetitania as a novel solid acid catalyst. Catal. Commun., 16: 50-55, doi:10.1016/ j.cat com.2011.08.029.

[27] Lasri, J., Aly, M.M., Eltayeb, N.E., Babgi, B.A. (2018). Synthesis of symmetrical and asymmetrical azines from hydrazones and / or ferrocene carboxaldehyde as potential antimic- robial-antitumor agents. J. Mol. Struct., 1164: 1-8, doi: 10.1016/j.molstruc.2018.03. 030 .

[28] Sadjadi, S., Rasouli, S. (2011). An efficient synthesis of imidazo[1,2-a]azine using nanocrystalline alumina powder. Int. J. Nano. Dim., 1(3): 177-186.

[29] Nanjundaswamy, H.M., Pasha, M.A. (2007). Rapid, Chemoselective and Facile Synthesis of Azines by Hydrazine/I 2 . Synth. Commun., 37: 3417-3420, doi: 10.1080/00397 9107 01483837.

[30] Anastas, P.T., Warner, J.C. (1998). Green Chemistry: Theory and Practice. Oxford University Press: New York, p. 30.

[31] Nagendrappa, G. (2011). Organic Synthesis Using Clay and Clay-Supported Catalysts. Applied Clay Science, 53(2): 106-138.

[32] Tanoli, M.A.K., Khan, Z., Maqsood, Z.T., Iqbal, L., Lateef, M., Hussain, Z., Kamal, T. (2014). Copper (II) Complexes of Bishydrazone Derivatives: Synthesis, Characterization and Urease Inhibition Studies, Middle. East. J. Sci. Res., 22 (5): 698-703, doi: 10.5829/idosi.mejsr.2014.22.05.21942

[33] Afsah, E.M., Elmorsy, S.S., Abdelmageed, S.M., Zaki, Z.E. (2015). Synthesis of some new mixed azines, Schiff and Mannich bases of pharmaceutical interest related to isatin. Z. Naturforsch., 70(6)b: 393-402. 
[34] Gholamzadeh, P., Ziarani, G.M., Badiel, A. (2016). Application of SBA-Pr- $\mathrm{SO}_{3} \mathrm{H}$ in the green synthesis of isatinhydrazone derivatives: Characterization, UV-Vis investigation and computational studies. J. Chil. Chem. Soc., 61(2): 2935-2939, doi: 10.40 67/ S071797072016000200017.

[35] Belbachir, M., Bensaoula, A. (2006). Composition and method for catalysis using bentonites. U. S. Pat., US 7,094,823 B2.
[36] Alali, K., Lebsir, F., Amri, S., Rahmouni, A., Srasra, E., Besbes, N. (2019). Algerian Acid Activated Clays as Efficient Catalysts for a Green Synthesis of Solketal by Chemo- selective Acetalization of Glycerol with Acetone. Bull. Chem. React. Eng. Catal., 14 (1): 130141, doi:10.9767/ bcrec.14.1.2445.130-141. 